Problems and some solutions: Ghana

By R. Orraca-TetTeH, Human Nutrition Research Unit, National Institute for Medical Research, The Ridgeway, Mill Hill, London, N.W.7

Ghana has three distinct geographical regions, the coastal plain, the forest belt and the northern savanna. The food habits of the people differ in the three regions.

In the northern savanna, bulrush-millet (Pennisetum typhoideum) and guinea corn (Sorghum vulgare Pers.) are the staple foods. Groundnut, (Arachis hypogaea), melon seeds, locust-bean seeds (Parkia filicoides) and shea butter (Butyrospermum Parkii) are also extensively used as everyday ingredients in soups and stews. Green leaves are consumed in the fresh state during the wet season; in the dry months they are used mainly in powder form. The leaves most frequently eaten are those of the baobab tree (Adansonia digitata) and of various species of hibiscus. In this region cattle and goats are reared, but are valued principally as property, being given mainly as dowries and only occasionally used for meat. The guinea-fowl thrives but guinea-fowl meat and eggs are not widely consumed. Fish is scarce; fresh fish is eaten only near the rivers.

In the forest region, the staple foods are mainly tubers and fruits, such as yams (Dioscorea sp.), cocoyam (Xanthosoma saggitifolium) and plantains (Musa paradisiaca). Cassava (Manihot utilissima) is also used. The green leaves of the cocoyam plant and the fruit of the garden egg plant (Solanum Melongena L.) are constant ingredients of the diet. Rice is grown and consumed in the wetter parts of the forest. Red palm oil extracted from the pericarp, the fleshy pericarp itself and the nuts of the palm (Elaesis guineensis) are also important. Fresh fish is scarce and most of the fish available is smoked or dried and comes from the coast. Catfish from the rivulets and streams is a delicacy. Goats are kept in open areas of the forest and eaten on ceremonial occasions. Cattle are imported from the north and the meat is eaten; some game is also eaten. During the rainy season forest snails (Archatina) are in abundant supply and are included in the diet. Snails are also smoked for storage.

The staple foods of the coastal belt are maize, cassava and plantains. Cowpeas (Vigna sp.) and groundnuts are used in soups and stews. Garden eggs, okra (Hibiscus esculentus), onions and various species of peppers (Capsicum sp.) are among the vegetables eaten daily. Red palm oil and palm nuts are frequently consumed. Many kinds of green leaves are eaten occasionally. Cattle and goats are reared on the drier parts of the plains and the meat is used, but it is very expensive. Poultry farming is becoming increasingly important. Fresh fish is a regular article of diet, consumption being particularly high in June, July and August.

Throughout Ghana, fresh cow's milk is scarce. The cows of the coastal plain and the northern savanna produce little milk. Evaporated and powdered milks are imported, but are too expensive for the average family.

\title{
Infant feeding
}

Children are breast fed for as long as 2 years. After the first $4-6$ months, supplementary foods are given. In the northern savanna, the traditional foods for infants 
and young children consist of paps and porridges prepared from millets; in the forest region and the coastal plain the main supplementary foods are maize paps and porridges. Apart from breast milk, most children receive no milk, though imported milk is purchased by well-to-do families. After the age of I year, toddlers share the family meals, but they are given hardly any of the fish and meat, which are delicacies reserved for the adults. Children thus receive a diet low in good-quality protein. Schoolchildren do not have school meals and depend upon vendors of cooked food to satisfy their hunger during the school day.

\section{Nutritional status of the people.}

In the northern savanna, the energy value of the diet may be adequate, about 2000$2500 \mathrm{kcal} / \mathrm{head}$ daily during the months after the harvest; but at the beginning of the wet season calorie deficiency is marked because food stores are low and heavy manual labour is necessary for food cultivation. Daily calorie intakes as low as $600 \mathrm{kcal} / \mathrm{head}$ have been reported from many areas. Some deaths from starvation occur from time to time. In the forest and coastal zones calorie levels are almost always high because of the heavy consumption of cassava, maize and plantains. There are, however, areas where supplies of energy foods may be deficient.

In the whole of Ghana, malnutrition due to protein deficiency associated with low haemoglobin levels is prevalent. In the south, where children have a relative excess of calories with little protein, the typical kwashiorkor picture is commonly found. In the north, where animal protein is scarce and calories are also deficient for part of the year, the 'marasmic' type of protein malnutrition is predominant. Platt \& Mayer (1958) have drawn attention to the high mortality rate in Ghana of children aged I-4 years and conclude that 'the underlying factor in most of this high mortality is malnutrition'. The ratio between the number of deaths in the ist year of life and in the age groups $\mathrm{I}-4$ is about $\mathrm{I} \cdot 35$, whereas in England and Wales it is $0 \cdot 28$. In certain parts of the northern region tropical ulcers are common among the children, leading to incapacity and to interference with school attendance. These ulcers have an infective basis and are slow to heal unless the patient is given a good diet and is in positive nitrogen balance (Platt, I953).

\section{Some solutions}

The first need is greater awareness on the part of the Government and people of the existence of malnutrition. The Government has evinced such awareness by setting up a Food and Nutrition Board to grapple with the problem. The next most important measure is the production of more food and particularly increased production of protein-rich foods.

In many areas meat, fish, eggs and other foods containing good-quality protein are not given to children in sufficient amounts, mainly because parents are ignorant of proper methods of child feeding. There is thus a need for vigorous instruction of mothers in the use of nutritionally sound methods of child feeding and the better use of available foods. Knowledge of the protein value of indigenous foods, determined 
chemically and by assays on animals, can inspire confidence in the formulation and recommendation of suitable mixtures of foods for children. The mixtures should consist of foods available to the ordinary family and must be cheap; examples include fish powder, eggs and pulses mixed with the maize and millet porridges. Table $\mathbf{I}$ shows some results of assays on animals of the protein value of Ghanaian diets based on dietary survey data (Grant, I955).

Table 1. The protein value of some Ghanaian diets

\begin{tabular}{llcccc}
\multicolumn{1}{c}{ Diet } & Protein Cals. \% & N.P.U. (op) $\%$ & N.D-p.v. & N.D-p. Cals. \% \\
I (Ghana, typical) & $9 \cdot 70$ & 53 & $5 \cdot 1$ & $5 \cdot 10$ \\
2 (Accra) & $8 \cdot 96$ & 56 & $5 \cdot 4$ & $5 \cdot 03$ \\
3 (Mampong) & $8 \cdot 60$ & 50 & 4.6 & $4 \cdot 43$ \\
4 (Ayeduase) & $9 \cdot 02$ & 64 & $5 \cdot 5$ & $5 \cdot 10$
\end{tabular}

According to Platt \& Miller ( 1959 ) a figure for N.D-p. Cals $\%$ below 8 indicates that the food or mixture concerned will not meet the requirements of infants and toddlers, pregnant and lactating women; the values for the diets studied do not reach this level.

The effect of improving diet $\mathrm{I}$ in various ways (based on work by D. S. Miller, $196 \mathrm{r}$, unpublished) is shown in Table 2.

Table 2. Effect of various supplements on the protein value of a Ghanaian diet

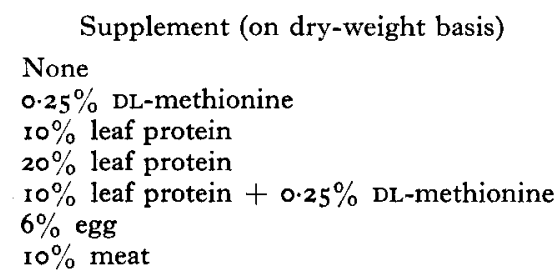

$\begin{array}{ccc}\text { Protein Cals. } \% & \text { N.P.U.(op) } \% & \text { N.D-p. Cals. \% } \\ 9 \cdot 7 & 53 & 5 \cdot 1 \\ 9 \cdot 7 & 53 & 5 \cdot 3 \\ 14 \cdot 4 & 41 & 5 \cdot 9 \\ \text { I9.0 } & 39 & 7 \cdot 6 \\ 14.4 & 53 & 7 \cdot 6 \\ \text { I I.2 } & 65 & 7 \cdot 3 \\ 17 \cdot 1 & 50 & 8 \cdot 5\end{array}$

Mixtures with other protein-rich foods are being studied in order to find those most suited to the people.

Given modern knowledge of food science, the real food situation can be appraised, and food technology can be brought to bear in improving local methods of food preservation and storage. For example, for a period of about 3 months in each year there is a great fishing boom; herring are caught in abundance and sell at ten for $3 \mathrm{~d}$. The local methods used in preserving this surplus are smoking and salting. Table 3 compares the quality of the protein of fish products preserved by these means with that of fish preserved by modern technical methods in European countries.

The smoked and sun-dried fish consumed in Ghana has a relatively low protein value, only about half that of fish products processed by modern technological methods. Thus the contribution of these products to the protein value of the diet 
Table 3. Protein value of fish treated by modern and traditional methods

Fresh fish
Kippers
Stockfish (dried)
Cod (salted)
Catfish (Adwen) (smoked)
Carp (Didei) (sun-dried)

$\begin{array}{lc}\text { Origin } & \text { N.P.U.(op) }(\%) \\ - & 90^{*} \\ \text { U.K. } & 8 \mathrm{I} \\ \text { Norway } & 91 \\ \text { Norway } & 69 \\ \text { Ghana } & 65 \\ \text { Ghana } & 57\end{array}$

*Value reported by Miller (1956) for carefully dried fish proteins from both oily and white fish of marine origin; values obtained for the biological value of the proteins (concentration in diet not stated) of freshwater fish range from 72 to $89 \%$ (Kuppuswamy, Srinivasan \& Subrahmanyan, I958).

could be nearly doubled by improvements in processing. This example illustrates the need for the application of food science and technology in the improvement of traditional and in the introduction of new methods of food preservation and storage.

\section{REFERENCES}

Grant, F. W. (1955). Nutrition and Health of Children in the Gold Coast. Chicago: University of Chicago Press.

Kuppuswamy, S., Srinivasan, M. \& Subrahmanyan, V. (1958). Spec. Rep. Ser. Indian Coun. med. Res. no. 33.

Miller, D. S. (1956). F. Sci. Fd Agric. 7, 337.

Platt, B. S. (1953). In Handbook of Tropical Dermatology and Medical Mycology. Vol. 2, p. 1480. [R. D. P. Simons, editor.] Amsterdam: Elsevier.

Platt, B. S. \& Mayer, J. (1958). Report of a Joint FAO/WHO Mission to Ghana.

Platt, B. S. \& Miller, D. S. (1959). Proc. Nutr. Soc. 18, vii.

\section{Some African problems}

By F. Aylward, Department of Chemistry and Food Technology, Borough Polytechnic, London, S.E.I

\section{Introduction}

This review must be selective both in the geographical sense and in the problems chosen for discussion. There are wide differences between the various countries and territories of Africa, but there are many problems common to those regions which can be regarded as economically underdeveloped. Such regions are characterized by a social pattern founded on village life with agriculture the great (and often the only) source of livelihood.

Medical opinion is unanimous that the high death rates in these agricultural communities must be traced in part to poor diets, and in particular: (I) to deficiencies in the total food supply (especially during the so-called hungry seasons-after poor harvests); (2) to deficiencies in food quality-notably shortages of protein and perhaps also of certain vitamins (such as ascorbic acid or members of the B complex). In effect (I) and (2) summarize the basic food problems of Africa, but further problems arise immediately remedies are sought. 